\title{
PERPINDAHAN PEMUKIMAN PENDUKUNG SITUS DAS SEKAMPUNG: JEJAK BENCANA MASA LAMPAU
}

\author{
The Movement of the Way Sekampung Watershed Site: A Past Disaster Track
}

\author{
Nurul Laili \\ Balai Arkeologi Jawa Barat \\ Jalan Raya Cinunuk km.17, Cileunyi, Bandung 40623
}

\begin{abstract}
Way Sekampung as Main River has the role in the growth of human civilization, from the past to the present. Archaeological traces show the growth of past civilizations with the presence of archaeological sites along the Sekampung watershed. This paper focuses on three sites located in the Sekampung Watershed in East Lampung, namely the Serampang, Cicilik, and Putak sites. The approach used is the material remains and collective memory through interviews. The results of the study show that the three sites are interrelated and it is possible that there has been a displacement of settlement due to a social disaster in the form of threaths and attack from the bajau (pirates).
\end{abstract}

Keywords: settlement, social disaster, displacement, Way Sekampung

\begin{abstract}
Abstrak
Way Sekampung sebagai sungai utama mempunyai peranan tumbuhnya peradaban manusia, dari masa lampau hingga kini. Jejak arkeologi menunjukkan adanya tumbuhnya peradaban masa lampau dengan hadirnya situs-situs arkeologi di sepanjang Daerah Aliran Sungai (DAS) Sekampung. Tulisan ini fokus pada tiga situs yang berada di DAS Sekampung Lampung Timur, yaitu Situs Serampang, Cicilik, dan Putak. Pendekatan yang digunakan dalam tulisan ini adalah pendekatan atas tinggalan materi dan memori kolektif dengan melalui wawancara. Hasil penelitian menunjukkan ketiga situs tersebut saling terkait dan dimungkinkan telah terjadi perpindahan hunian yang diakibatkan adanya bencana sosial berupa teror dan serangan bajau (bajak laut).
\end{abstract}

Kata kunci: hunian, bencana sosial, perpindahan, Way Sekampung

\section{PENDAHULUAN}

Aktivitas manusia masa lampau dapat diketahui dari jejak materi yang ditinggalkan. Material tersebut dapat berupa artefak, ekofak, fitur, maupun situs. Aktivitas manusia masa lampau seperti halnya manusia masa sekarang, tentu menyisakan jejak tinggalan tergantung dengan jenis aktivitas, seperti perdagangan, penguburan, dan permukiman. aktivitas perbengkelan tentunya berbeda dengan aktivitas religi, penjagalan, atau bercocok tanam. Jejak-jejak aktivitas tersebut menunjukkan bahwa manusia pendukungnya sudah berada pada tingkat budaya bermukim pada suatu tempat.

Kata pemukiman dan permukiman mempunyai definisi yang berbeda, pemukiman dapat didefinisikan sebagai tempat orang bermukim, secara fisik dapat dilihat dengan mata, sedangkan permukiman mengacu pada hal-hal yang berkenaan 
dengan pemukiman, sehingga istilah permukiman lebih luas pengertiannya daripada pemukiman (Mundardjito 1990). Bentuk pemukiman dapat dibagi menjadi tiga yaitu pemukiman sederhana, pemukiman desa, dan pemukiman kota (Said, 2006). Pemukiman sederhana dalam penentuan lokasi bermukim salah satunya ditentukan oleh kondisi lingkungan, sedangkan permukiman desa biasanya sudah menetap, berkelompok dalam jumlah yang kecil, dan muncul spesialisasi profesi, adapun permukiman kota adalah masyarakat sudah majemuk dan secara keruangan lebih luas (Said, 2006).

Pemukiman selalu menempati ruang tertentu. Demikian halnya dengan pendukung situs di sepanjang Way Sekampung untuk bermukim memilih lokasi di sepanjang daerah aliran sungai Sekampung. Sungai memiliki sumber daya yang dapat memenuhi kebutuhan hidup manusia masa lampau antara lain adanya sumber air, aksesbilitas yang memudahkan manusia bergerak, dan faktor makanan.

Way Sekampung merupakan sungai besar dan mempunyai peranan sangat penting baik pada manusia masa lampau ataupun masa kini. Bagian hulu Way Sekampung bermata air di Gunung Sekincau. Ketinggian Gunung Sekincauberada pada ketinggian \pm 1718 meter di atas permukaan air laut, sedangkan muara berada di pantai timur utara Sumatra. Way Sekampung sebagai sungai utama mempunyai sejumlah anak sungai, diantaranya Way Pisang bermata air di Gunung Rajabasa ( $\pm 1281 \mathrm{~m} \mathrm{dpl}$ ), Way Ketibung, Way Galih, dan Way Kandis bermata air di Gunung Betung ( $\pm 1256 \mathrm{~m} \mathrm{dpl}$ ), serta Way Ilahan bermata air di Bukit Rindingan ( $\pm 1508 \mathrm{~m} \mathrm{dpl}$ ) (Tim Analisis, 1999/2000). Dengan kata lain aliran Way Sekampung terbentang dari Sekampung Hulu di Kabupaten Tanggamus, Sekampung Tengah di Kabupaten Lampung Tengah, dan Sekampung Hilir di Kabupaten Lampung Timur. Kondisi sekarang DAS Sekampung merupakan lumbung pangan utama atau produsen pangan pokok, komoditas ekspor dan produk perikanan, serta produsen pangan penting lain (Arifin, Yuwono, dan Ismono 2018).

Demikian halnya di masa lampau, sepanjang Way Sekampung juga banyak jejak arkeologi berupa situs-situs pemukiman. Situs-situs tersebut, adalah kompleks Batu Bedil, Gelombang, Bukit Wungkal (Silitonga), Pejambon, Sidomukti, Pugung Raharjo, Bentengsari, Parigi, Gedig, Cicilik, Meris, dan Prasasti Bungkuk (Triwurjani 1995, 2011), Situs Serampang/Serappang, dan Situs Putak. (Laili 2007, 2008). Diantara sebaran situs di sepanjang Way Sekampung, tiga diantaranya yaitu Situs Serampang, Cicilik, dan Putak menjadi fokus pada artikel ini. Ketiga situs tersebut mempunyai keterkaitan berkait dengan perpindahan dari lokasi satu ke lokasi yang lain akibat bencana.

Kata bencana dalam Kamus Besar Bahasa Indonesia (KBBI) mempunyai pengertian sebagai sesuatu yang menyebabkan (menimbulkan) kesusahan, kerugian, atau penderitaan ${ }^{1}$. Adapun dalam bahasa Inggris yang diambil dari kamus Cambridge, bencana disebut sebagai disaster, calamity, debacle, havoc, yang secara umum

\footnotetext{
${ }^{1}$ (https://www.kbbi.web.id/bencana, diakses 09, Maret, 2021)
} 
mempunyai pengertian "an event resulting in great loss and misfortune" (suatu peristiwa yang mengakibatkan kerugian besar dan kemalangan) (Cambridge Advanced Learner's Dictionary, Cambridge: Cambridge University Press, 2008), entry disaster.

Bencana dapat disebabkan oleh faktor alam, non alam, dan manusia. Oleh karena itu, Undang-Undang Nomor 24 Tahun 2007 tersebut juga mendefinisikan mengenai bencana alam, bencana nonalam, dan bencana sosial. Bencana alam adalah bencana yang diakibatkan oleh peristiwa atau serangkaian peristiwa yang disebabkan oleh alam antara lain berupa gempa bumi, tsunami, gunung meletus, banjir, kekeringan, angin topan, dan tanah longsor. Bencana nonalam adalah bencana yang diakibatkan oleh peristiwa atau rangkaian peristiwa nonalam yang antara lain berupa gagal teknologi, gagal modernisasi, epidemi, dan wabah penyakit. Adapun bencana sosial adalah bencana yang diakibatkan oleh peristiwa atau serangkaian peristiwa yang diakibatkan oleh manusia yang meliputi konflik sosial antarkelompok atau antarkomunitas masyarakat, dan teror (UU RI No 24 Tahun 2007 ).

Artikel ini fokus pada peristiwa yang diakibatkan oleh perpindahan permukiman akibat adanya teror. Permasalahan yang dikedepankan pada artikel ini adalah apakah terdapat perpindahan pemukiman dari Situs Serampang, Cicilik, dan Putak yang disebabkan oleh teror sebagai salah satu bentuk ataupun wujud bencana. Hal tersebut didasarkan pada tinggalan arkeologi dan memori kolektif masyarakat setempat.

Penyelesaian permasalahan tersebut dilakukan dengan pendekatan kebudayaan materi yaitu dengan dengan melakukan pengamatan langsung pada artefak (artifact oriented analysis (Said, 2006:5). Telaah secara detil dan rinci perlu dilakukan untuk menghindari bias mengingat sifat data arkeologi merupakan cerminan tingkah laku masa lampau (Schiffer, 1976: 11-12). Pengumpulan data dilakukan melalui survei dan wawancara.

Telaah yang digunakan merupakan analisis keramik dan tembikar, diawali dari analisis morfologi/bentuk, analisi teknologi, analisis gaya/styalistik. Langkah selanjutnya adalah interpretasi dan simpulan (Simanjuntak 2008). Keramik dapat memberikan informasi tentang asal pembuatan dan masa pembuatan. Dengan demikian temuan keramik dapat menggambarkan waktu secara relatif pada aktivitas suatu situs. Melalui kajian keramik, yaitu dengan masa relatif yang sama akan diketahui kemungkinan terdapatnya perpindahan penduduk antar ketiga situs dan berlangsung dalam waktu yang masih sejaman, seperti yang digambarkan pada bagan alir di bawah ini. Berikut bagan alir analisis artefak keramik (Bagan 1): 


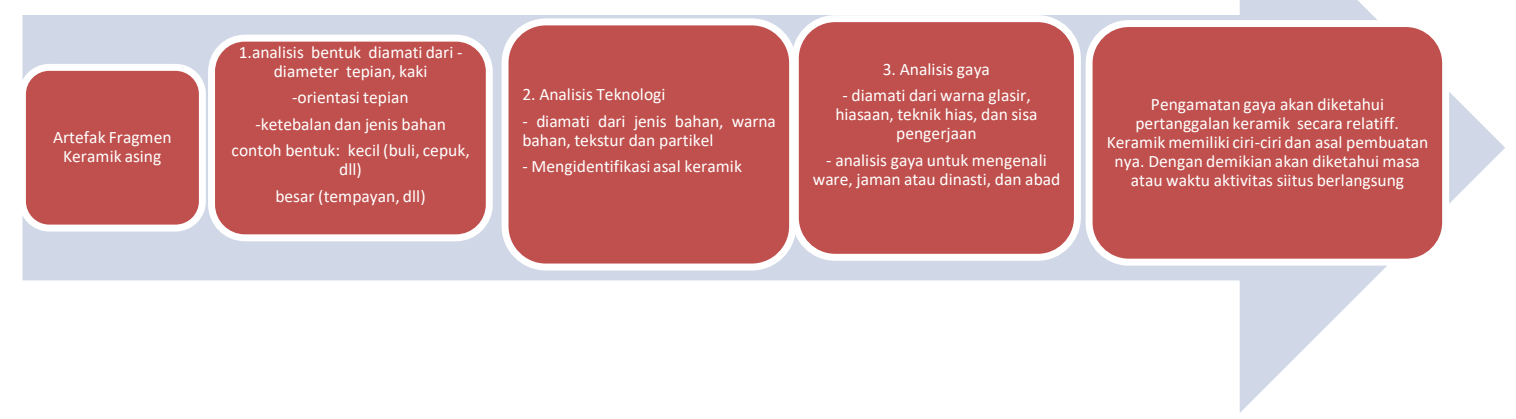

Bagan 1. Bagan alir analisis artefak keramik

\section{PEMBAHASAN}

\section{Situs-Situs Di Sepanjang Way Sekampung}

Situs-situs arkeologi di sepanjang Way Sekampung dari hulu hingga hilir di antaranya adalah Gelombang, Pejambon, Pugungraharjo, Gedig, Perigi, Cicilik, Meris, Bentengsari, Serampang, dan Putak (Triwurjani 2011; Laili 2007; Laili 2008). Situs yang menggambarkan adanya perpindahan ataupun pergerakan manusia pendukung didasarkan dari hasil wawancara dan survei berjumlah tiga situs, yaitu Situs Serampang, Cicilik, dan Putak (Gambar 1).

Situs Serampang secara administratif, berada di Dusun Serampang, Desa Serampang Pusingan, Kecamatan Rawa Sragi, Kabupaten Lampung Timur. Secara geografis situs berada di tepi selatan Way Sekampung, berada di daerah hilir dan berjarak dengan muara $\pm 4,5 \mathrm{~km}$. Muara Way Sekampung dikenal dengan nama Kuala Sekampung (Laili, 2008). Situs berada pada pedataran dengan tinggalan arkeologis berupa tumulus, 21 fragmen tembikar, dan 136 fragmen keramik asing. Tumulus merupakan gundukan tanah buatan yang membukit. Pada masa prasejarah, khususnya pada masyarakat tradisi megalitik, makam-makam sering dibuat dalam bentuk seperti itu (Atmodjo 1999).

Berdasarkan hasil temuan arkeologis, Situs Serampang merupakan situs permukiman ataupun hunian. Jejak arkeologis yang dapat diindikasikan sebagai situs pemukiman diperoleh dari identifikasi fragmen tembikar dan keramik. Tembikar yang diperoleh menunjukkan perlengkapan sehari-hari berupa periuk, buyung, dan pasu. Adapun fragmen keramik yang diperoleh juga termasuk dalam tipe wadah berupa mangkuk, tempayan, dan piring. Pertanggalan relatif keramik berasal dari Eropa (abad ke-19 - ke-20 M), keramik Cina dari masa Dinasti Qing (abad ke-17 - ke-20 M), dinasti Ming (abad ke 14 - ke-17 M, dan keramik Thailand (abad ke-13 - ke-17 M).

Situs Cicilik secara administratif berada di wilayah Desa Asahan, Kecamatan Jabung, Kabupaten Lampung Timur. Keletakan situs berada di tepi Sungai Cicilik yang merupakan anak Way Sekampung. Situs Cicilik berada pada lahan datar yang berbenteng dan berparit. Daerah benteng merupakan kebun dengan luas \pm 2 ha. Benteng area situs dikelilingi parit (Triwurjani 1995; Triwurjani 2011; Tim Analisis, 1999/2000; 
Laili, 2008). Jejak arkeologis di Situs Cicilik berupa watu kandang, fragmen tembikar, fragmen keramik, manik manik, kerak besi, dan punden. Temuan batu kandang berupa hamparan monolit yang terdiri atas dolmen dan altar batu.

Berdasatkan tinggalan arkeologi yang ada maka Situs Cicilik terindikasi sebagai situs hunian. Identifikasi fragmen tembikar menunjukkan sebagai wadah berupa periuk, kendi, dan pasu, Adapun fragmen keramik yang diperoleh menunjukkan jenis peralatan sehari-hari berupa mangkuk, tempayan, guci dan piring. Pertanggalan relatifdiperoleh dari temuan keramik. Berdasarkan analisis keramik menunjukkan temuan berasal dari Eropa (abad ke-19 - ke-20 M), keramik Cina dari masa Dinasti Qing (abad ke17 - ke20 M), dinasti Ming (abad ke-14 - ke-17 M), Song (abad ke-10 - ke-11 M), dan Thailand (abad ke-13 - ke-17 M).

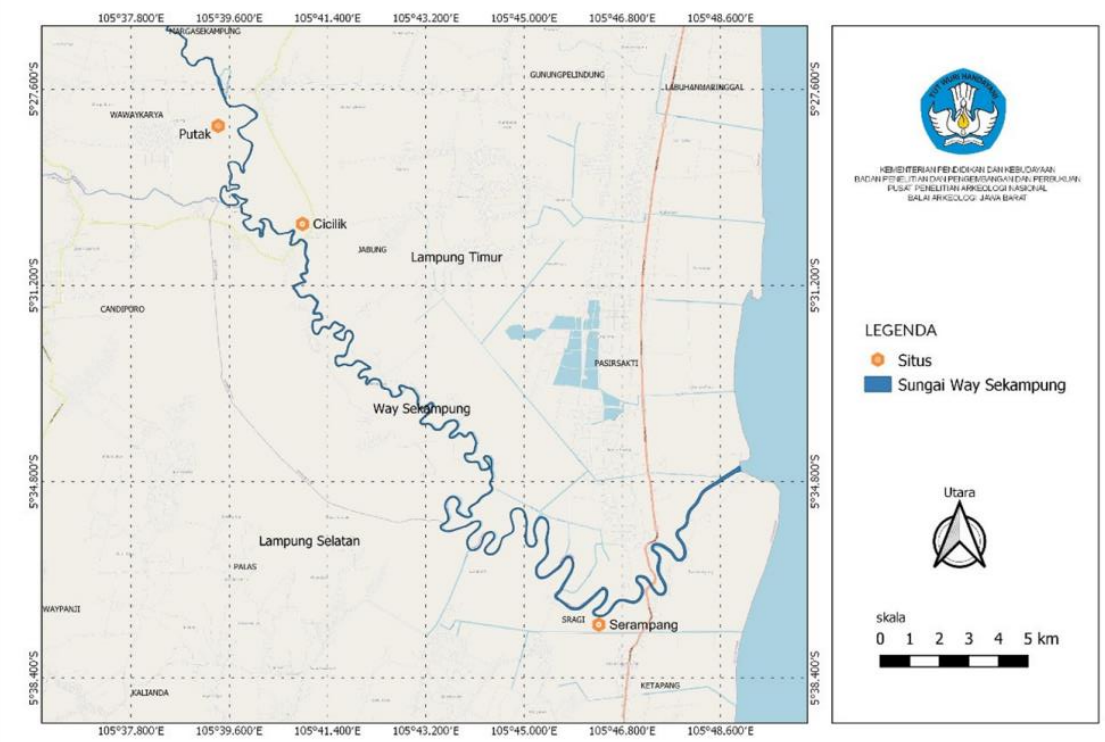

Gambar 1. Sebaran situs di DAS Way Sekampung Sumber: Dokumen Balai Arkeologi Jawa Barat

Situs Putak secara administratif berada di Desa Marga Batin, Kecamatan Waway Karya, Kabupaten Lampung Timur. Lahan situs merupakan pedataran berada di tepian sisi barat Way Sekampung. Pembagian ruang di Situs Putak terdiri atas dua ruang, ruang pertama merupakan lahan datar dengan temuan sebaran frgamen tembikar dan keramik asing, Ruang lain berupa kompleks makam yang ditata secara berundak. Makam terdiri atas jirat dan nisan. Nisan atau penanda kubur berupa batu tegak berbahan andesitik.

Hasil analisis yang dilakukan pada fragmen tembikar sulit untuk dikenali karena keseluruhan fragmen merupakan bagian badan dengan ukuran relatifkecil. Adapun untuk fragmen keramik asing merupakan jenis wadah berupa piring dan mangkuk, berasal dari Eropa (ke-19 - ke-20 M), keramik Cina dari masa Dinasti Qing (ke-17 - ke$20 \mathrm{M}$ ), dan dinasti Ming (ke-14 - ke-17 M). 


\section{Catatan Memori Kolektif Masyarakat}

Catatan memori kolektif masyarakat diperoleh dari Shaleh, Kepala Desa Jabung berdasarkan catatan yang ditulis pada tanggal 28 Haji 1346 bertepatan dengan tanggal 27 Juni 1928. Legenda yang merupakan ingatan kolektif ini diceritakan oleh Raja Tihang Marga dan Raja Mangku Alam.

Nenek moyang masyarakat Jabung setelah keluar dari kampung Sekalo Berak yaitu sewaktu zaman Poyang Serunting. Salah satu anaknya yang bernama Sultan Gumai Jangguk Suwaso mempunyai anak bernama yaitu Sultan Guru. Sultan Guru tersebut mempunyai 4 orang anak, yaitu:

1. Anak pertama, Pengeran Pak tinggal di Tulang Bawang Negri Besar - Way Kanan;

2. Anak kedua, Pesiwo Batin /atau sering dikenal dengan nama Sunan Marga;

3. Anak ketiga, Pendekar Sakti atau sering dikenal dengan nama Temengguk Pendekar Sakti,

4. Anak keempat adalah perempuan dan merupakan istri Jimat Batin / Pengeran Ugor di Lampung

Cerita Jabung dimulai dari keturunan Pesiwo Batin. Pesiwo Batin memiliki tiga orang anak, yaitu Kemas Drayo, Taring Blawan, dan Ingga di Lawi. Pesiwo Batin dan ketiga anak menghadap Sultan Banten - Hasanudin. Di Banten mereka menghadap sultan dan menyatakan maksud kedatangan dari Lampung. Mereka menyatakan akan pindah ke Jawa dan mendirikan kampung. Maksud dan tujuan mereka dikabulkan oleh Sultan Hasanudin Banten. Tanah yang akan mereka jadikan kampung harus dibayar dengan harga sebesar 40 real atau seharga 80 rupiah. Kampung baru tersebut dinamakan Kampung Pengabuan Banten.

Nama Pesiwo Batin di Kampung Pengabuhan berganti menjadi Sunan Marga Waliya Dua Tahun kemudian Pesiwo Batin dan keluarga merasa tidak cocok untuk tinggal di Kampung Pengabuhan karena adat istiadat agak berbeda. Selanjutnya mereka menghadap kembali Sultan Maulana Hasanudin untuk kembali ke Lampung Permintaan tersebut dikabulkan oleh Sultan Banten.

Sultan Banten memberikan tanah di Kuala Way Sekampung. Pesiwo Batin dan keluarga diharuskan membayar tanah tersebut seharga 80 real atau 160 rupiah. Selanjutnya nama kampung tersebut dinamakan Serampang. Lokasi Serampang berhadapan dengan Labuhan Ratu. Jarak kampung tersebut dari laut kira-kira $1 \mathrm{~km}$.

Sultan Banten menentukan batas tanah dengan orang Melinting, yaitu dari laut Kuala-Nyelai naik ke darat Lebung Sekampung yaitu diantara Kampung Gunung Sugih dan Negri Agung Belah 2 Gunung Urai hingga ke Siring BaniaK Batu Pengajar Beringin Jajar. Batas sekampung udik Batu Badak/Muara Cekang hingga hulu Pekarang Bintang. Batas dengan Marga Ketibung Pematang Samang Annakyaitu Siring Ralom terus di muara Belob/ Batu Payung terus Ilir Belah 2 Way sekampung hingga batas Kuala NyBeberapa waktu kemudian, Serampang merupakan kampung yang tidak aman. Bajau dari laut sering datang ke kampung tersebut dan mengambil beberapa harta dengan paksa. Kondisi ini menyebabkan Sultan Banten mengirimkan seorang jawara 
bernama Mas Krajan atau Batin Dato dan tinggal di kampung tersebut selama 2,5 tahun sebelum kemudian pindah ke Putak.

Batin Dato oleh Sultan Banten diberi gelar Temenggung Jago Pati. Batin Dato membawa oleh-oleh dari Banten berupa burung putih kepala, kentang, penyu, kayu melako, dan kayu jati yang ditanam di daerah Cicilik.

\section{Perpindahan Permukiman Situs Das Sekampung}

Berdasarkan memori kolektif masyarakat menunjukkan adanya tiga nama tempat atau lokasi di sepanjang Way Sekampung, yaitu Serampang, Cicilik, dan Putak yang saling terkait satu sama lain. Survei atau pun pengamatan permukaan pada ketiga lokasi tersebut, mendapatlkan jejak tinggalan arkeologi yang dapat disajikan melalui (Tabel 1)

Tabel 1. Situs, Jenis Temuan, dan Pertanggalan Relatif

\begin{tabular}{|c|c|c|c|}
\hline \multirow{2}{*}{$\begin{array}{l}\text { Jenis Temuan/ } \\
\text { Pertanggalan }\end{array}$} & \multicolumn{3}{|c|}{ Nama Situs } \\
\hline & Serampang & Cicilik & Putak \\
\hline Tembikar & Periuk, Buyung, Pasu & Periuk, pasu, kendi & - \\
\hline Keramik asing & $\begin{array}{l}\text { Mangkuk, tempayan, } \\
\text { piring }\end{array}$ & $\begin{array}{l}\text { Piring, mangkuk, } \\
\text { tempayan, guci }\end{array}$ & Piring dan mangkuk, \\
\hline Punden & ada & Ada & Tidak \\
\hline Makam & tidak & Ada & Ada \\
\hline $\begin{array}{l}\text { Pertanggalan } \\
\text { Relatif }\end{array}$ & $\begin{array}{l}\text { Eropa (abad ke-19- ke- } \\
20 \mathrm{M} \text { ), keramik Cina } \\
\text { dari masa dinasti Qing } \\
\text { (ke-17 - ke-20 M), } \\
\text { dinasti Ming (ke-14 - } \\
\text { ke-17 M), dan Thailand } \\
\text { (ke-13-ke-17 M). }\end{array}$ & $\begin{array}{l}\text { Eropa (abad ke-19 - } \\
\text { ke-20 M),keramik } \\
\text { Cina dari dinasti Qing } \\
\text { (ke-17 - ke-20 M), } \\
\text { dinasti Ming (ke-14 - } \\
\text { ke-17 M), Song (ke- } \\
10-\text { ke-11 M), dan } \\
\text { Thailand (ke-13 - ke- } \\
17 \mathrm{M}) .\end{array}$ & $\begin{array}{l}\text { Eropa (ke-19- ke-20 } \\
\text { M), keramik Cina } \\
\text { dari dinasti Qing } \\
\text { (abad ke-17 - ke-20 } \\
\text { M), dan dinasti Ming } \\
\text { (abad ke-14 - ke-17 } \\
\text { M) }\end{array}$ \\
\hline
\end{tabular}

Tinggalan arkeologi sebagai bukti terdapatnya jejak aktivitas manusia dapat menggambarkan fungsi situs (Said, 2006). Berdasarkan data yang terdapat pada (Tabel 1) dengan jenis temuan berupa tembikar, keramik, punden, dan makam menunjukkan situs-situs tersebut merupakan situs hunian.

Tembikar merupakan barang-barang yang dibuat dari tanah liat dicampur dengan pasir, pecahan kerang, sekam padi, bahkan dengan pecahan tembikar yang dihaluskan (grog) dengan pembakaran berkisar antara $350^{\circ}-1000^{\circ}$ Celcius. Adapun keramik asing biasanya berupa stoneware dan porselin, dibuat dari tanah liat bersifat silica/kaca, tidak tembus cahaya, tidak menyerap air, biasanya dibakar pada suhu antara $1500^{\circ}$ sampai $1300^{\circ} \mathrm{C}$ (stoneware) dan $1250^{\circ}$ sampai $1300^{\circ} \mathrm{C}$ (porselin) (Simanjuntak 2008). Secara morfologi atau bentuk, tembikar dan keramik asing di tiga situs terkategori sebagai wadah yang merupakan bagian dari peralatan sehari-hari. Tembikar tersebut antara lain berupa periuk, pasu, dan kendi, sedangkan keramik asing berupa piring, mangkuk, 
tempayan, dan guci. Temuan lain berkait dengan pemukiman yang bersifat sakral adalah struktur punden dan makam. Punden dan makam biasanya berkait dengan pemujaan dan pengagungan ataupun penghormatan terhadap moyang mereka. Punden merupakan struktur yang disusun meninggi (Atmodjo 1999).

Pemukiman ataupun hunian di Situs Serampang, Cicilik, dan Putak berdasarkan pengolahan data memori kolektif masyarakat menunjukkan adanya perpindahan hunian. Hunian diawali dari Situs Serampang setelah perpindahan dari Banten, kemudian pindah setelah terlebih dahulu ke Cicilik untuk menanan kayu, dan terakhir bermukim di Putak. Perpindahan pemukiman disebabkan oleh serangan bajau yang sering menyerang Serampang.

Istilah bajau berasosiasi dengan bajak laut atau perompak sungai, menurut Wallace bajau adalah singkatan ataupun sebutan dari perkataan bajak laut (Wallace, 1971). Bajau pada masyarakat Lampung sudah dikenal lama, salah satu penggambaran keberadaan Bajau melalui tarian tradisional Lampung yaitu tari Perang Bajau. Tari Perang Bajau merupakan suatu tari yang terinspirasi dari cerita turun-temurun di daerah Tulangbawang, Menggala, Lampung. Tari Perang Bajau menceritakan perang besar yang terjadi antara perompak Cina dengan masyarakat Tulangbawang. Karya tari ini menggambarkan suasana ketidaknyamanan rakyat Tulangbawang atas peristiwa perampokan dan pembantaian yang terjadi sehingga masyarakat bangkit dan melawan perompak (Diantori 2012).

Keberlangsungan aktivitas di Situs Serampang, Cicilik, dan Putak berdasarkan pertanggalan relatif ditunjukkan oleh beberapa temuan keramik asing. Kereamik asing tersebut, diantaranya Eropa, Cina, dan Thailand. Keberlangsung aktivitas di ketiga situs tersebut terdapat rentang yang hampir sama. Kronologi yang dapat digambarkan dari ketiga situs terjelaskan dari temuan fragmen keramik asing baik Eropa, Cina, maupun Thailand. Secara relatif diperoleh data bahwa keramik berasal dari Eropa dengan rentang abad ke-19 - ke-20 M, keramik Cina dari masa dinasti Qing dengan rentang abad ke-17 - ke-20 M, dinasti Ming dengan rentang abad ke 14-17 M), Song dengan rentang abad 10-11 M, dan keramik Thailand yang berkembang pada abad ke-13 - ke17 M. Dengan demikian penghunian di ketiga situs, yaitu Serampang, Cicilik, dan Putak diduga dihuni mulai abad ke-13 $\mathrm{M}$ dan intensif dihuni sekitar abad ke-16 - ke-17 M.

\section{SIMPULAN}

Perpindahan hunian di ketiga situs di aliran Way Sekampung, berdasarkan kajian memori kolektif dan tinggalan arkeologis disebabkan adanya petaka/bencana sosial berupa teror dari bajau. Hal tersebut mengakibatkan terjadi perpindahan lokasi hunian situs dari Serampang ke Cicilik dan berakhir di Putak. Perpindahan hunian dibuktikan oleh adanya tinggalan arkeologis berupa fragmen keramik asing dan secara relatif menunjukkan waktu yang sejaman. Hal menarik lainnya, ketiga situs, yaitu Serampang, Cicilik, dan Putak selain sebagai hunian profan juga menunjukkan adanya ruang sakral yang ditunjukkan oleh adanya makam dan punden. 


\section{DAFTAR PUSTAKA}

Arifin, Bustanul, Slamet Budi Yuwono, dan Hanung Ismono. 2018. "Pengendalian Risiko Lingkungan di DAS Sekampung, Lampung." Bandar Lampung.

Atmodjo, Junus Satrio dkk. 1999. Vademekum Benda Cagar Budaya. Jakarta: Departemen Pendidikan dan Kebudayaan.

Diantori, Mr. 2012. “Perang Bajau.” Joged Jurnal Seni Tari 3 No 2.

Laili, Nurul. 2007. "Laporan Hasil Penelitian Arkeologi Pemukiman Tradisi Masa Prasejarah di Kawasan Labuhan Ratu dan Way Kanan, Kabupaten Lampung Timur, Provinsi Lampung." Bandung.

—. 2008. "Pemukiman Tradisi Masa Prasejarah di Kawasan Serampang Rawa Sragi dan sekitarnya, Kabupaten Lampung Timur, Provinsi Lampung.” Bandung.

Mundardjito. 1990. "Metode Penelitian Permukiman Arkeologis." In Monumen: Lembaran Sastra Seri Penerbitan Ilmiah No. 11, Edisi Khus. Depok: Fakultas Sastra Universitas Indonesia.

Said, Chaksana A.H dan Utomo, Bambang Budi. 2006. "Pemukiman dalam Perspektif Arkeologi.” In Pemukiman di Indonesia Perspektif Arkeologi, diedit oleh Triwurjani dkk, 1-15. Jakarta.

Simanjuntak, Truman. 2008. Metode Penelitian Arkeologi. Jakarta: Pusat Penelitian Arkeologi Nasional-Kementerian Pendidikan dan Kebudayaan.

Tim Analisis. 1999/2000. "Permukiman dan Niaga Kuna di DAS Sekampung, Provinsi Lampung.” Jakarta.

Triwurjani. 1995. “Alokasi Situs-Situs Arkeologi di Kawasan DAS Way Sekampung." Berkala Arkeologi Vol 15 No: 177-79. https://doi.org/10.30883/jba.v15i3.691.

Triwurjani, Rr. 2011. Situs-Situs Megalitik di DAS Sekampung. Pertama. Jakarta: Wedatama Widya Sastra.

UU RI No 24 Tahun 2007 Penanggulangan Bencana. 2007.

Wallace, Ben J. 1971. Village Life Insular Southeast Asia. Boston: Methodist University Little Brown Company.

\section{HASIL DISKUSI}

\section{Tidak Ada Pertanyaan}

